\title{
THE ROLE OF TICKS IN THE TRANSMISSION OF SELECTED BACTERIAL PATHOGENS OF HUMAN DISEASES
}

\section{ZNACZENIE KLESZCZY W TRANSMISJI WYBRANYCH PATOGENÓW CHORÓB BAKTERYJNYCH CZŁOWIEKA}

\author{
Patrycja Teodorowicz $^{1(\mathrm{E}, \mathrm{F})}$, Marcin Weiner $^{2(\mathrm{E}, \mathrm{F})}$ \\ ${ }^{1}$ Medical Laboratory, Innovation Research Center, \\ John Paul II University of Applied Sciences in Biala Podlaska, Poland \\ ${ }^{2}$ Department of Agriculture, John Paul II University of Applied Sciences in Biala Podlaska, Poland
}

Authors' contribution Wkład autorów: A. Study design/planning zaplanowanie badań B. Data collection/entry zebranie danych C. Data analysis/statistics dane - analiza i statystyki D. Data interpretation interpretacja danych E. Preparation of manuscript przygotowanie artykułu F. Literature analysis/search wyszukiwanie i analiza literatury G. Funds collection zebranie funduszy

Tables: 0

Figures: 2

References: 44

Submitted: 2022 Jan 19

Accepted: 2022 Feb 11

\section{Summary}

Ticks and the pathogens they transmit are an ever-present global health problem. In Poland, the most common species of these arachnids are Ixodes ricinus (castor bean tick) and Dermacentor reticulatus (ornate cow tick). There are risks associated with the parasitic effects of ticks. During their feedings, they can have direct and indirect effects on the affected host. Both arthropod species are characterized by a large number of microorganisms species they transmit causing bacterial, viral, and parasitic diseases. Bacterial infections are the most common among tick-borne diseases. These include Lyme disease, human granulocytic anaplasmosis, tularemia, and $Q$ fever. An increasingly common clinical issue prompting the current research is co-infections, i.e. simultaneous infection of the host by several pathogens. An infection caused by multiple pathogens results in severe and atypical symptoms, prolonged duration of disease, as well as reduced response to treatment. Taking into account the ubiquity of ticks in the environment, only a thorough understanding of tick-borne diseases, including infectious agents and vectors, can lead to better control of this problem worldwide.

Keywords: human granulocytic anaplasmosis, co-infections, Q fever, Lyme disease, tularemia

\section{Streszczenie}

Kleszcze oraz przenoszone przez nie patogeny wciąż stanowią aktualny problem zdrowotny o charakterze globalnym. W Polsce najbardziej rozpowszechnionymi gatunkami tych pajęczaków są kleszcze Ixodes ricinus (kleszcz pospolity) i Dermacentor reticulatus (kleszcz łąkowy). Możliwe zagrożenia związane są z pasożytniczym oddziaływaniem kleszczy. Ich żerowanie wywiera bezpośredni i pośredni wpływ na zaatakowany organizm. Oba gatunki stawonogów charakteryzują się dużą liczbą gatunków przenoszonych mikroorganizmów, wywołujących choroby bakteryjne, wirusowe oraz pasożytnicze. Infekcje bakteryjne są najbardziej liczną grupą spośród chorób odkleszczowych. Zalicza się do nich m.in. boreliozę, anaplazmozę granulocytarną, tuleremię i gorączkę Q. Coraz częściej pojawiającym się zagadnieniem klinicznym, stanowiącym aktualny problem badawczy, są koinfekcje, czyli współzakażenie organizmu kilkoma patogenami. Zakażenie spowodowane przez różne patogeny skutkuje występowaniem nasilonych i nietypowych objawów, wydłużonym czasem trwania choroby, jak również brakiem odpowiedzi organizmu na zastosowane leczenie. Biorąc pod uwagę wszechobecność kleszczy w środowisku, tylko dokładne zrozumienie chorób odkleszczowych, w tym czynników zakaźnych oraz wektorów, może doprowadzić do lepszej kontroli tego problemu na całym świecie.

Słowa kluczowe: anaplazmoza granulocytarna, koinfekcje, gorączka Q, borelioza, tularemia

Copyright: (C) John Paul II University of Applied Sciences in Biala Podlaska, Patrycja Teodorowicz, Marcin Weiner. This is an Open Access journal, all articles are distributed under the terms of the Creative Commons Attribution-NonCommercial-ShareAlike 4.0 International (CC BY-NC-SA 4.0) License (http://creativecommons. org/licenses/by-nc-sa/4.0/), allowing third parties to copy and redistribute the material in any medium or format and to remix, transform, and build upon the material, provided the original work is properly cited and states its license. 


\section{Introduction}

The negative impact of tick-borne diseases on public health has been present for several decades. Between 1940 and 2004, zoonotic diseases accounted for more than $60 \%$ of all human infectious diseases. Of these, $22.8 \%$ were infections involving tick vectors [1]. Tick-borne pathogens and the diseases they cause are a current and increasing human health problem worldwide. This problem is closely linked to the constantly increasing incidence of ticks, the vectors responsible for human transmission. This increase is attributed to many factors such as climate change which is one of the major contributors. The climate is warming up with shorter, milder winters and higher humidity levels affecting a range of habitats for ticks. As a result, the duration the arachnid is active is being extended. This disrupts the established patterns of peak occurrences during the months of May-June and September-October.

Rapid urbanization and habitat modification are other factors. Until recently, the main habitat for ticks was meadows and wooded areas. However, these arachnids are increasingly being seen in cities where people, through the promotion of healthy lifestyles, spend more time outdoors without adequate protection against ticks [2]. This phenomenon is also influenced by economics, population growth, and population fluctuations. Additionally, internal changes within ticks and improved adaptation mechanisms to survive result in an increase their abundance [3].

In turn, the emergence of new pathogens may be related to the high variability and plasticity of the pathogens' genomes [4]. Fortunately, the awareness and seriousness of the effects tick-borne diseases cause are steadily growing. The knowledge gained about ticks, the pathogens they transmit, and the symptoms of the diseases these pathogens cause is increasing at many levels. Research being conducted on the cellular and molecular levels is essential to understand the characterization and pathogenesis of these pathogens [1].

\section{Aim of the work}

This study examines select contemporary issues concerning vectors, pathogens, and tick-borne diseases.

\section{Ticks as vectors of infection}

Ticks belongto the subclass Acari, class Arachnida, phylum Arthropods, and are group of vectors characterized by a high diversity of transmitted pathogens. They are present worldwide and, depending on the species, are found in a diverse range of wet and dry environments. To date, 900 species of ticks have been identified [5]. They are divided into two families: hard ticks (Ixodidae) and soft ticks (Argasidae). Ixodidae contains over 700 species that are divided into 7 genera, of which Ixodes, Dermacentor, Haemaphysalis, Hyalomma, Amblyomma, and Rhipicephalus are the main ones [5]. In Poland, there are 19 species of ticks of which Ixodes ricinus (castor bean tick, Figure 1) and Dermacentor reticulatus (ornate cow tick, Figure 2) are the most common. Current research identifies I. ricinus as the vector for the largest number of pathogen species. D. reticulatus transmits a smaller number of microbial species and feeds mainly on animals. Overall, the highest incidence of tick-borne infections are recorded for pathogens of the Borrelia spp., Babesia spp., Rickettsia spp. and Anaplasma spp. [6]. 


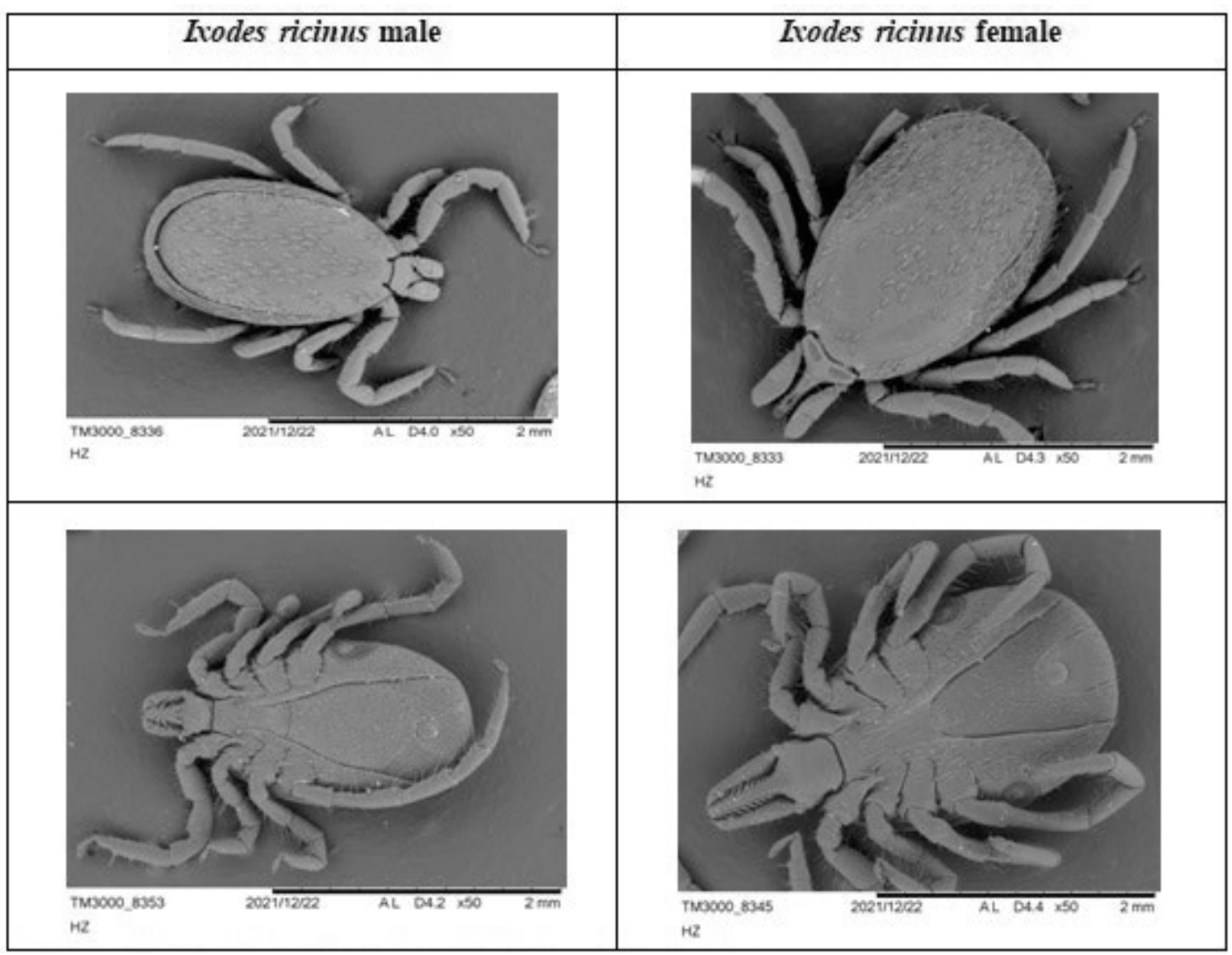

Figure 1. Morphological structure of the female and male Ixodes ricinus tick

Notes: Photographs taken by Estera Michaluk, PhD, using a scanning electron microscope (SEM) at the IT and Construction Laboratory of the Innovation Research Center of the John Paul II University of Applied Sciences in Biala Podlaska, Poland. 


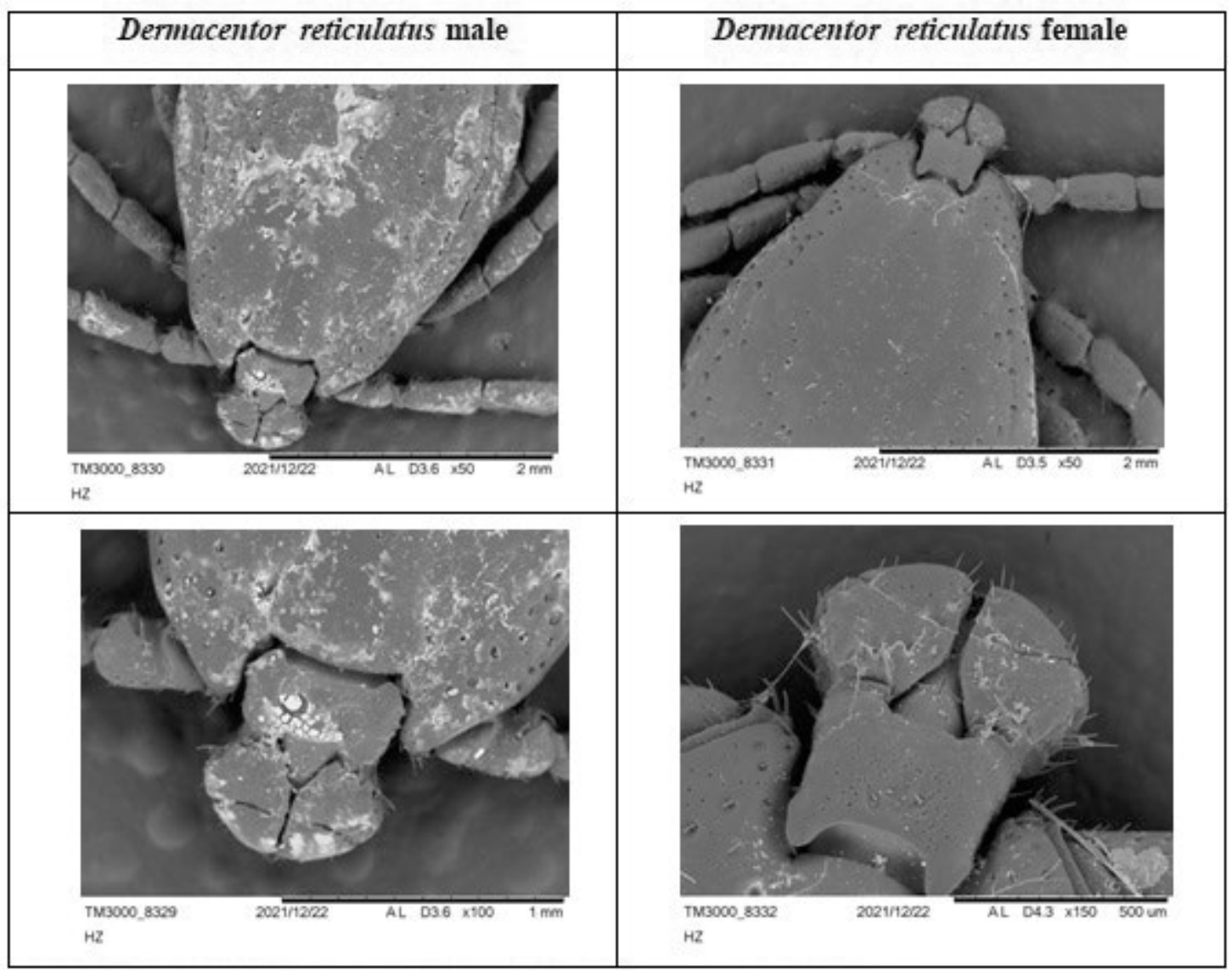

Figure 2. Morphological structure of the female and male Dermacentor reticulatus tick

Notes: Photographs taken by Estera Michaluk, PhD, using a SEM at the IT and Construction Laboratory of the Innovation Research Center of the John Paul II University of Applied Sciences in Biala Podlaska, Poland.

There are risks associated with the parasitic effects of ticks. Their feeding has direct and indirect effects on the affected host. Ticks go through four stages of development: eggs, larvae, nymphs, adult male/female. For each stage, blood must be ingested by them to cause molting. Therefore they consume blood at every stage of their development cycle. Although ticks typically parasitize only once during each life stage, they may have several hosts if they do not complete the feeding [7]. This enables them to transmit many pathogens that cause infectious diseases such as Lyme disease, granulocytic anaplasmosis, tularemia, and Q fever.

A tick's search for a host is essential for their survival and, for this reason, they have a very sophisticated system for detecting the right hosts [5]. Organs such as the sensory setae or Heller's organ allow arachnids to respond to odors, radiating heat, and breath. The odors they are attracted to include the ammonia in urine and animal feces, as well as the butyric acid and lactic acid found in sweat. In their search for a host, they additionally respond to stimuli such as vibration, sound, and touch [3]. Hard ticks usually bite during the day and after approximately 24 hours, the cells of the salivary glands break down allowing the release of pathogens into the host [8]. The act of a blood draw can occur in two ways: slow and rapid. Slow blood drawing in females can last up to 10 days, increase their body weight from 2 to $50 \mathrm{mg}$, and gently stretch their body shells. Redness is often observed at the puncture site. Rapid suction lasts from 12 to 24 hours and is associated with a weight increase of $50 \mathrm{mg}$ to as much as $250 \mathrm{mg}$. During this stage, the blood drawn is concentrated by returning it to the body of the host [9]. Regardless of species, ticks can draw up to $3 \mathrm{~cm}^{3}$ of blood during a feeding period. In the case of larvae and nymphs, the amounts are much smaller and there is usually no inflammation making the diagnosis of infestation much more difficult.

Pathogens can persist in a tick for a long time resulting in their transmission. Transmission can be vertical as pathogens are transmitted from females to their eggs or horizontal from tick to tick via a host. The longer the duration of a blood draw the higher the risk of infection [10]. The pathogens carried by ticks are located in the salivary glands, midgut, hemolymph, and reproductive system. Although they are highly pathogenic towards 
vertebrates these pathogens rarely cause symptoms in the body of the arachnid. However, pathogens have been observed to cause developmental disorders, interfere with organ functioning, and in severe infections that kill the tick. The literature shows tick mortality to be highest from infections of the Babesia spp. protozoan [11]. Studies on nymphs have suggested infection with $B$. burgdorferi s.l. spirochaetes can affect a tick's host-seeking activity [12] and resistance to low temperatures [13]. Pathogens in the body of ticks multiply facilitating their migration and colonization of the next host [14]. Consequently, they undoubtedly are a group of great importance in the spread of infections.

\section{Tick-borne diseases}

Ticks are responsible for transmitting many infectious agents including bacteria, viruses, and parasites. The health problems associated with these micro-organisms include mainly zoonotic diseases transmitted while humans are used as accidental hosts. It should also be noted that the presence of these pathogens in ticks alone does not necessarily result in an infection. In the case of bacteria and parasites, the transmission does not occur immediately. These pathogens must migrate towards the salivary glands of the arachnids, a process that takes up to 24 hours [15].

\section{Borrelia burgdorferi and Lyme disease}

Lyme disease is the most common tick-borne bacterial disease in Europe, and its main vector is I. ricinus. The etiological agent of this infection is the highly motile $B$. burgdorferi s.l. spirochetes. These spirochetes can adopt varying sizes and shapes depending on the environment in which they are found. They are microaerophiles that live as both external and intracellular parasites during different periods of their life cycle [16]. The reservoir for B.burgdorferi s.l. consists of numerous animal species but rodents are the most common. B.burgdorferi s.l. is a highly invasive agent and is responsible for a large number of infections in Poland. The National Institute of Hygiene in Poland (org. Państwowy Zakład Higieny, PZH) reported 20,629 cases in 2019 [17]. Worldwide, there are 12 genera in the $B$. burgdorferi complex, however, not all of them cause human infections.

Lyme borreliosis is very difficult to diagnose due to its variable clinical presentation and incubation period of 2 to 4 weeks. Based on signs and symptoms, Lyme disease is classified into three stages: early localized, early disseminated, and late disseminated. In the early localized stage of the disease, symptoms include fever, chills, headache, fatigue, muscle/joint pain, and rashes consisting of at least one erythema migrans (EM). The early disseminated stage can occur a few days to a few weeks after the onset of symptoms. During this stage, patients continue to experience fever, fatigue, headache, and muscle/joint pain. However, the appearance of more severe symptoms affecting the neurologic and circulatory systems develop. These can include nerve palsies, symptomatic neuropathies, meningitis, heart palpitations, fainting, chest pain, and shortness of breath. Inflammatory cardiomyopathy is a rare complication that can occur when the spirochetes attack heart tissue with symptoms appearing on average 2 and 4 weeks after onset of Lyme disease. In the late disseminated stage of Lyme disease, the symptoms become chronic. Patients can develop neurologic abnormalities commonly referred to as neuroborreliosis in addition to chronic arthritis, severe pain in the extremities, and multiple inflammatory conditions [18].

The preliminary diagnosis of Lyme disease is based on serological ELISA testing. If a positive or doubtful result is obtained, a western blot test is performed to confirm the diagnosis. Treatment consists of antibiotic therapy for 2 to 4 weeks but can vary based on provider preference. Additionally, there is no permanent immunity against Lyme disease, therefore, if a patient is constantly exposed to tick bites, the disease may recur [3].

\section{Anaplasma phagocytophilum and human granulocytic anaplasmosis (HGA)}

HGA is a severe infectious disease that was originally described in the United States where it became known as granulocytic ehrlichiosis caused by Ehrlichia phagocytophilum. However, a taxonomic change identified the organism belonged to the genus Anaplasma resulting in a name change to Anaplasma phagocytophilum [19]. A. phagocytophilum is a Gram-negative bacterium that attacks white blood cells (neutrophils, monocytes, macrophages) and is mainly located in the vacuoles of cells. The most frequent vectors for this pathogen are ticks of the Ixodidae family: Ixodes ricinus in Europe, Ixodes persulcatus in Asia, and Ixodes scapularis, Ixodes pacificus, and Ixodes spinipalpis in North America. The number of anaplasmosis cases in humans are steadily increasing. $A$. phagocytophilum also causes tick fever in ruminants, anaplasmosis in horses, and febrile illnesses in cats and dogs [20]. 
Characteristic symptoms of HGA include fever, headache, hematological abnormalities including leukopenia and thrombocytopenia, and increased serum aminotransferase as a parameter indicative of liver damage. Symptoms typically appear 5 to 14 days after coming into contact with an infected tick. Most cases of granulocytic anaplasmosis occur in areas with a high prevalence of Lyme disease and babesiosis - which may indicate that the transmission of these three pathogens are by the same vector species [21]. Ticks infected with A. phagocytophilum are found throughout Poland with frequencies ranging from $4 \%$ in western Poland to $15 \%$ in the area of Białystok in eastern Poland [16]. Each year, dozens of people report symptoms consistent with HGA infection. Typically, the disease is self-limited for immunocompetent individuals with a mortality rate of $<1 \%$. However, in immunocompromised patients, the elderly, patients undergoing treatment with immunosuppressive agents, and cancer patients the mortality varies between 7-10\% [22].

During the first week of the disease, diagnosis is based on the direct detection of DNA from the HGA etiologic agent using polymerase chain reaction (PCR) testing. The sensitivity of the PCR test varies between 67-90\%. Microscopic examination of the peripheral blood smear with staining using a Giemsa stain has a sensitivity of $25-70 \%$. The diagnosis can also be based on the detection of antibodies which usually appear 7-14 days after the onset of disease symptoms.

The treatment of human granulocytic anaplasmosis is considered on an individual basis, but the most commonly used group of antibiotics are tetracyclines with doxycycline being used the most. The duration of antibiotic therapy is important for complete recovery, especially in mixed infection, and should consist of 7-14 days [23-25].

\section{Rickettsia spp. and spotted fevers}

Rickettsia bacteria are small, Gram-negative pathogens that are transmitted by ticks. They are primarily responsible for spotted fevers with about 30 rickettsial species have been identified. According to the European Centre for Disease Prevention and Control, 5,903 cases were diagnosed in Europe between 2000 and 2010 [26].

Rickettsioses causing spotted fevers are characterized by non-specific clinical symptoms. The incubation time from the moment of contact with a tick is on average 3 to 12 days. Symptoms associated with infection include fever, headache, muscle/joint pain, and a maculopapular rash. There is often a scab at the site of the tick bite. The symptoms are usually mild and treatment consists of taking doxycycline for 7-14 days [26].

Serological testing is a popular diagnostic method for rickettsioses, but seroconversion does not occur for about 20 days. Molecular studies can also be conducted to detect a common gene within the group of bacteria that causes spotted fevers [26].

\section{Francisella Tularensis and tularemia}

Tularemia is a highly contagious zoonotic disease caused by a Gram-negative, aerobic bacilli named Francisella tularensis. This group of bacteria is divided into two subspecies: F. tularensis subsp. tularensis (type A), whose presence has been reported in North America, Austria, and Slovakia, and F. tularensis subsp. holarctica (type B), seen throughout the northern hemisphere and Australia [27]. These pathogens are found in various regions of the world but remain relatively scarce, although their numbers are increasing. The reservoirs of these microorganisms are mainly rodents, mice, rats, squirrels, hares, rabbits, and wild birds. F. tularensis can be transmitted to humans through the skin, conjunctiva, oral or respiratory routes, contact with infected animals, contaminated aerosols, contaminated food/water, and vectors such as Ixodes and Dermacentor ticks [28].

Depending on the mode of entry of $F$. tularensis, the following clinical forms of the disease are distinguished: ulcerative-nodular, ocular-nodular, anginal, visceral, and pulmonary. Tularemia can produce asymptomatic, mild, or acute diseases. In Europe, more than $95 \%$ of cases occur after contact with an infected tick and take the ulcerative-nodular form. The incubation period depends on the infecting dose and the virulence of the pathogen, but, on average, it is short, lasting 3 to 4 days [29]. Initially, the disease begins with acute and influenza-like with general debility, high fever, chills, headache, and muscle/joint pain. If symptoms are overlooked and not treated properly complications may occur. In $30 \%$ of tularemia patients, they can develop lymph node abscesses. Less commonly, meningitis and infections of the heart, bone, and soft tissue can occur [27].

Given the varied symptoms, the diagnosis of tularemia is based on serological, microbiological, and molecular tests. Serum tests evaluate for the presence of both IgM and IgG antibody levels. Antibodies to F. tularensis antigens appear in the patient's blood 10 to 14 days after the onset of the first clinical symptom with the highest levels observed after 4-7 weeks of infection. Microbiological tests are based on the cultivation of microorganisms from clinical materials such as sputum, throat swabs, blood, and gastrointestinal samples. Such analyses are 
a valuable source of information with regard to the diagnosis of infection, epidemiology, and differentiation of F. tularensis bacilli. Molecular methods, e.g. PCR and its variations, make it possible to search for bacterial gene fragments in various types of clinical materials [29].

\section{Coxiella burnetii and Q fever}

Q fever is a common zoonotic disease around the world with cases having also been reported in Poland. The Gram-negative bacterium responsible for this infection is Coxiella burnetii. They are initially found in monocytes and macrophages of humans and animals and from there spreads to tissues. C. burnetii is highly infectious - the presence of as few as 10 bacterial cells can cause infection. Commonly, these microorganisms are found in two forms: a large-cell, proliferating variant (LCV) and a small-cell, non-proliferating variant (SCV) [30,31].

The reservoirs for $C$. burnetii include mainly cattle, sheep, goats, but also reptiles, birds, and marine mammals can be a source of infection. The respiratory route is the most common way in which infections can develop through contact with infected animals. Bacteria can also be found in contaminated urine, raw milk, feces, and animal carcasses [32,33]. Ticks play a secondary role in the spread of $C$. burnetii infections, although it is estimated that approximately 40 species may serve as reservoirs for these bacteria. In 2018, ticks collected in north-eastern Poland were found to harbor $C$. burnetii bacteria at a rate of $0.45 \%-3.45 \%$ [34].

The clinical manifestations of $Q$ fever are mainly flu-like: fever, headache, and joint/muscle pain with atypical pneumonia and hepatitis occurring in later stages. The incubation time ranges from 9 to as many as 40 days. Fortunately, these infections are rare as epidemiological data in Poland have only reported one case since 2010 [31].

The diagnosis of $Q$ fever is based both on serological and molecular tests. Serologic tests aim to determine the presence of antibodies against $C$. burnetii in the patient's blood. While molecular tests try to detect bacterial DNA in clinical samples [35].

\section{Co-infections}

An increasingly growing research and clinical problem is that of tick-borne co-infections. It is a phenomenon in which one organism is infected by several pathogens of different types, but also by microorganisms belonging to the same genus, causing so-called mixed infections [36]. A significant number of co-infections involve two to three etiological agents which typically include Borrelia burgdorferi s.l., Anaplasma phagocytophilum, and Babesia spp. An infection caused by multiple pathogens results in severe and atypical symptoms, prolonged duration of disease, as well as reduced response to treatment [6,37].

The best-known co-infection in ticks and humans is the co-infection of A. phagocytophilum and B. burgdorferi s.l. This co-infection results in an accelerated and increased entry of Borrelia spirochetes into human internal organs resulting in a more severe progression of Lyme disease [38]. This occurs because of the immunomodulatory actions of $A$. phagocytophilum. This bacterium affects the activity of granulocytes impairing the ability of the infected organism's immune system making it easier for a second pathogen to colonize. The easier penetration into tissues by B. burgdorferi s.l. and the more severe course of Lyme disease is due to a decrease in interferon and interleukin-12 levels caused by the co-infection with A. phagocytophilum [39].

The prevalence of co-infections in tick vectors is influenced by their geographical distribution and by endemic infections among them and their hosts. Currently, co-infection studies are being conducted worldwide in common tick species, i.e. Ixodes ricinus and Dermacentor reticulatus. Reis et al. [40] collected 227 I. ricinus ticks in France and demonstrated co-infections in $16.3 \%$. They found the most common co-infections were with Borrelia spp. and Anaplasma spp. (5.75\%). The authors of this study consider this phenomenon to be very common in this tick species given their diversity of hosts. Co-infections with B. burgdorferi s.l. and A. phagocytophilum in Ixodes ricinus ticks collected from north-eastern Poland was also shown by Roczeń-Karczmarz et al. [41]. In their study, out of the 236 ticks that were collected, $14 \%$ were found to be co-infected with these two pathogens. In Germany, Hildebrandt et al. [42] detected co-infections with Coxiella burnetii. Among the 1,000 ticks collected, Borrelia spirochetes were involved in $87.5 \%$ of the co-infections. The study further investigated 9 out of the 19 Coxiellapositive ticks. One tick was found to be infected with $C$. burnetii and $B$. microti. Two nymphs were found to have a triple co-infection with C. burnetii, B.burgdorferi s.l., and B. garinii in one, and C. burnetii, Rickettsia Helvetica, and B.burgdorferi s.l. in the second.

Compared to Ixodes ricinus ticks, the Dermacentor reticulatus species are considered a less competent vector for pathogens. However, new findings on tick-borne pathogens seem to be slowly pushing this thesis into oblivion. The numbers of etiological agents detected in infections are still lower than in I. ricinus overall, but this 
is steadily increasing when compared to previous years. In addition, the importance of D. reticulatus as a vector is significantly weakened by the relatively short activity period as nymphs and their ability to survive without a host for 3-4 years [8]. In 2017, Zając et al. [43] collected 634 ticks from eastern Poland. Their analyses found co-infections with two pathogens in 54 (8.5\%) samples, among which a co-infection with A. phagocytophilum and Tick-borne encephalitis virus (TBEV) was detected in $0.32 \%$. In Serbia, Tomanovic et al. [44] examined 53 D. reticulatus ticks and detected co-infections in 18.9\%. The majority of these co-infections were with Francisella spp. and Babesia canis (17.0\%), and, in one case, Francisella spp. and C. burnetii. In south-eastern Poland, coinfections in Dermacentor reticulatus ticks were studied by Roczeń-Karczmarz et al. [41]. Of the 237 specimens analyzed, a co-infection with B. burgdorferi s. l. and A. phagocytophilum was detected in $12.24 \%$.

As demonstrated, the literature illustrates the clinical significance of co-infections in both Ixodes ricinus and Dermacentor reticulatus. However, the co-infection phenomenon itself has been studied more extensively for $I$. ricinus.

\section{Conclusions}

Since the beginning of the $20^{\text {th }}$ century, there has been an increase in the number of ticks, the emergence of new species, and a constantly expanding geographical distribution range. The main consequence of their feeding is the transmission of pathogens causing diseases in humans and animals, including Lyme disease, granulocytic anaplasmosis, tularemia, and Q fever. At the same time, public awareness of tick-borne diseases, their pathogens, and vectors is increasing. Ticks have and always will be a real threat to public health as it is impossible to eliminate arachnids from the human biotope. For this reason, measures have to be taken to find out more about them and reduce the risk and incidence of the diseases. This requires increased efforts in detecting infected ticks and the pathogens they transmit, reporting human cases, and collecting accurate data on the overall risk. From an analytical standpoint, it is important to increase database information on the microbiome of ticks and to understand the mechanisms involved in transmission to be aware of their potential as vectors. All these efforts are made to ensure that doctors, veterinarians, and health professionals have access to up-to-date information on recognized and newly emerging infectious agents. The early diagnosis and selection of appropriate treatment can reduce serious infections and complications associated with tick-borne diseases.

It is also important to educate the public about the real danger of ticks and the need for preventive actions. Unfortunately, there is no way to absolutely, $100 \%$ protect against tick attacks. However, preventive measures including the use of repellents, appropriate protective clothing, and checking one's body are important to do each time one goes outdoors. In conclusion, and taking into account the ubiquity of ticks in the environment, only a thorough understanding of tick-borne diseases, including infectious agents and vectors, can lead to better control of this problem worldwide.

\section{Disclosures and acknowledgments}

The authors declare no conflicts of interest with respect to the research, authorship, and/or publication of this article. The research was funded by the Employee Development Fund of John Paul II University of Applied Sciences in Biala Podlaska - research project PB/25/2020 “Molecular Tests for Tick-borne Pathogens".

\section{References:}

1. Wikel SK. Ticks and tick-borne infections: complex ecology, agents, and host interactions. Veterinary Sciences. 2018; 5(2): 60. https://doi.org/10.3390/vetsci5020060

2. Teodorowicz $\mathrm{P}$, Weiner M. Current methods used to identify and genotype spirochaetes Borreliella burgdorferi. Health Prob Civil. 2020; 14(2): 71-82. https://doi.org/10.5114/hpc.2020.93808

3. Weiner M, Teodorowicz P, Niźnikowska E. Resistance and rational actions as effective counter-measures in the struggle against Lyme disease. Archives of Budo. 2020; 16: 173-180.

4. Kmieciak W, Ciszewski M, Szewczyk EM. [Tick-borne diseases in Poland: prevalence and difficulties in diagnostics]. Medycyna Pracy. 2016; 67(1): 73. https://doi.org/10.13075/mp.5893.00264

5. Boulanger N, Boyer P, Talagrand-Reboul E, Hansmann Y. Ticks and tick-borne diseases. Mèdecine et Maladies Infectieuses. 2019; 49(2): 87-97. https://doi.org/10.1016/j.medmal.2019.01.007

6. Grochowska A, Pancewicz S, Czupryna P, Dunaj J, Borawski K, Moniuszko-Malinowska A. Pathogens carried by Ixodes ricinus and Dermacentor reticulatus ticks, including coinfections. Przegląd Epidemiologiczny. 2020; 74(3): 466-474. https://doi.org/10.32394/pe.74.40 
7. Richter D, Debski A, Hubalek Z, Matuschka FR. Absence of Lyme disease spirochetes in larval Ixodes ricinus ticks. Vector-Borne and Zoonotic Diseases. 2012; 12(1): 21-27. https://doi.org/10.1089/vbz.2011.0668

8. Lachmajer J, Wegner Z. [Medical arachnoentomology]. In: Kadłubowski R., editor. [An outline of medical parasitology: a textbook for medical students]. Warszawa: PZWL; 1988. p. 287-333 (in Polish).

9. Zajkowska JM. [Transmission and circulation of tick borne pathogens (TBE and Lyme borreliosis) and the role of changing environment]. Przegląd Epidemiologiczny. 2010; 64(4): 525-531 (in Polish).

10. Randolph S, Gern L, Nuttall P. Co-feeding ticks: epidemiological significance for tick-borne pathogen transmission. Parasitol Today. 1996; 12: 472-479. https://doi.org/10.1016/S0169-4758(96)10072-7

11. Kiewra D. [Assessment of the vector role of Ixodes ricinus L. 1758 (Acari, Ixodidae) ticks in the transmission of Borrelia burgdorferi s.l. in Poland, with particular emphasis on the Lower Silesia region]. Wrocław: I-Bis; 2014 (in Polish).

12. del Fabbro S, Trifonova T, D’Agaro, Caracciolo I, Nazzi F. Borrelia burgdorferi s.l. infection and questing activity of Ixodes ricinus nymphs: preliminary data. Abstract book "XII International Jena Symposium on Tick-borne Diseases", 2013 March 21-23, Weimar, Germany.

13. Hermann C, Gern L. Survival of Ixodes ricinus nymphs under cold conditions is influenced by sampling season and temperature variations, and to a lesser extent by infection with Borrelia burgdorferi sensu lato. Abstract book "XII International Jena Symposium on Tick-borne Diseases", 2013 March 21-23, Weimar, Germany.

14. Lewandowski D, Urbanowicz A, Figlerowicz M. [Molecular interactions between Borrelia burgdorferi ticks and mammals]. Postępy Mikrobiologii. 2013; 52(1): 9-16 (in Polish).

15. de la Fuente J, Contreras M, Estrada-Pena A, Cabezas-Cruz A. Targeting a global health problem: vaccine design and challenges for the control of tick-borne diseases. Vaccine. 2017; 17. https://doi.org/10.1016/j. vaccine.2017.07.097

16. Tylewska-Wierzbanowska S, Chmielewski T. Tick-borne bacterial diseases in Poland. Health Prob Civil. 2017; 11(2): 56-65. https://doi.org/10.5114/hpc.2017.69017

17. Czarkowski MP, Staszewska-Jakubik E, Wielgosz U. [Infectious diseases and poisonings in Poland in 2020]. Warsaw: National Institute of Public Health NIH - National Research Institute, Department of Epidemiology and Surveillance of Infectious Diseases; 2021 (in Polish).

18. Madison-Antenucci S, Kramer LD, Gebhardt LL, Kauffman E. Emerging tick-borne diseases. Clinical Microbiology Reviews. 2020; 33(2): e00083-18. https://doi.org/10.1128/CMR.00083-18

19. Stuen S, Granquist EG, Silaghi C. Anaplasma phagocytophilum - a widespread multi-host pathogen with highly adaptive strategies. Frontiers in Cellular and Infection Microbiology. 2013; 3: 31. https://doi.org/10.3389/ fcimb.2013.00031

20. Rar V, Golovljova I. Anaplasma, Ehrlichia, and “Candidatus Neoehrlichia” bacteria: pathogenicity, biodiversity, and molecular genetic characteristics, a review. Infection, Genetics and Evolution. 2011; 11(8): $1842-1861$. https://doi.org/10.1016/j.meegid.2011.09.019

21. Rikihisa Y. Mechanisms of obligatory intracellular infection with Anaplasma phagocytophilum. Clinical Microbiology Reviews. 2011; 24(3): 469-489. https://doi.org/10.1128/CMR.00064-10

22. Woźniak A, Zając Z, Kulisz J, Bartosik K. [Selected rarely occurring tick-borne diseases in humans. Infectious and parasitic diseases - research perspectives]. Lublin: Wydawnictwo Naukowe Tygiel; 2018 (in Polish).

23. Biggs HM, Behravesh CB, Bradley KK, Dahlgren FS, Drexler NA, Dumler JS, et al. Diagnosis and management of tickborne rickettsial diseases: Rocky Mountain spotted fever and other spotted fever group rickettsioses, ehrlichioses, and anaplasmosis-United States: A practical guide for health care and public health professionals. Morbidity and Mortality Weekly Report: Recommendations and Reports. 2016; 65(2): 1-44. https://doi.org/10.15585/mmwr.rr6502a1

24. Bakken JS, Dumler JS. Human granulocytic anaplasmosis. Infectious Disease Clinics. 2015; 29(2): 341-355. https://doi.org/10.1016/j.idc.2015.02.007

25. Dumler JS, Madigan JE, Pusterla N, Bakken JS. Ehrlichioses in humans: epidemiology, clinical presentation, diagnosis, and treatment. Clinical Infectious Diseases. 2007; 45: 45-51. https://doi.org/10.1086/518146

26. Borawski K, Dunaj J, Pancewicz S, Król M, Czupryna P, Moniuszko-Malinowska A. Tick-borne rickettsioses in Europe - a review. Przegląd Epidemiologiczny. 2019; 73(4): 523-530. https://doi.org/10.32394/pe.73.49

27. Maurin M. Francisella tularensis, tularemia and serological diagnosis. Frontiers in Cellular and Infection Microbiology. 2020; 10: 646. https://doi.org/10.3389/fcimb.2020.512090

28. Tomaso H, Otto P, Peters M, Süss J, Karger A, Schamoni H, et al. Francisella tularensis and other bacteria in hares and ticks in North Rhine-Westphalia (Germany). Ticks and Tick-Borne Diseases. 2018; 9(2): $325-329$. https://doi.org/10.1016/j.ttbdis.2017.11.007 
29. Chróst A, Gielarowiec K, Kałużewski S, Rastawicki W. The occurrence of infections caused by Francisella tularensis in humans in Poland and laboratory diagnosis of tularemia. Medycyna Doświadczalna i Mikrobiologia. 2017; 69: 55-63 (in Polish).

30. Gwida M, El-Ashker M, Khan I. Q fever: a re-emerging disease. Journal of Veterinary Science and Technology. 2012; 3(5). https://doi.org/10.4172/2157-7579.1000120

31. Borawski K, Dunaj J, Pancewicz S, Król M, Czupryna P, Moniuszko-Malinowska A. Coxiella burnetii and Q fever-a review. Przegląd Epidemiologiczny. 2020; 74(1): 43-48. https://doi.org/10.32394/pe.74.05

32. EFSA (European Food Safety Authority). Scientific Opinion on Q fever, Parma, Italy. EFSA Journal. 2010; 8: 1595-1909. https://doi.org/10.2903/j.efsa.2010.1595

33. Szymańska-Czerwińska M, Jodełko A, Niemczuk K. Occurrence of Coxiella burnetii in Polish dairy cattle herds based on serological and PCR tests. Comparative Immunology, Microbiology and Infectious Diseases. 2019; 67:101377. https://doi.org/10.1016/j.cimid.2019.101377

34. Bielawska-Drozd A, Cieślik P, Żakowska D, Głowacka P, Wlizło-Skowronek B, Zięba P, et al. Detection of Coxiella burnetii and Francisella tularensis in tissues of wild-living animals and in ticks of north-west Poland. Polish Journal of Microbiology. 2018; 67(4): 529. https://doi.org/10.21307/pjm-2018-059

35. Melenotte C, Protopopescu C, Million M, Edouard S, Carrieri MP, Eldin C, et al. Clinical features and complications of Coxiella burnetii infections from the French National Reference Center for Q fever. JAMA Network Open. 2018; 1(4): e181580-e181580. https://doi.org/10.1001/jamanetworkopen.2018.1580

36. Lommano E, Bertaiola L, Dupasquier C, Gern L. Infections and coinfections of questing Ixodes ricinus ticks by emerging zoonotic pathogens in Western Switzerland. Applied and Environmental Microbiology. 2012; 78(13): 4606-4612. https://doi.org/10.1128/AEM.07961-11

37. Diuk-Wasser MA, Vannier E, Krause PJ. Coinfection by Ixodes tick-borne pathogens: ecological, epidemiological, and clinical consequences. Trends in Parasitology. 2016; 32(1): 30-42. https://doi. org/10.1016/j.pt.2015.09.008

38. Nyarko E, Grab DJ, Dumler JS. Anaplasma phagocytophilum-infected neutrophils enhance transmigration of Borrelia burgdorferi across the human blood brain barrier in vitro. International Journal for Parasitology. 2006; 36(5): 601-605. https://doi.org/10.1016/j.ijpara.2006.01.014

39. Nieto N, Foley JE. Meta-analysis of coinfection and coexposure with Borrelia burgdorferi and Anaplasma phagocytophilum in humans, domestic animals, wildlife, and Ixodes ricinus-complex ticks. Vector-Borne and Zoonotic Diseases. 2009; 9(1): 93-102. https://doi.org/10.1089/vbz.2008.0072

40. Reis C, Cote M, Paul RE, Bonnet S. Questing ticks in suburban forest are infected by at least six tickborne pathogens. Vector-Borne and Zoonotic Diseases. 2011; 11(7): 907-916. https://doi.org/10.1089/ vbz.2010.0103

41. Roczeń-Karczmarz M, Dudko P, Demkowska-Kutrzepa M, Meisner M, Studzińska M, Junkuszew A, et al. Comparison of the occurrence of tick-borne diseases in ticks collected from vegetation and animals in the same area. Medycyna Weterynaryjna. 2018; 74(8): 484-488. https://doi.org/10.21521/mw.6107

42. Hildebrandt A, Straube E, Neubauer H, Schmoock G. Coxiella burnetii and coinfections in Ixodes ricinus ticks in central Germany. Vector-Borne and Zoonotic Diseases. 2011; 11(8): 1205-1207. https://doi.org/10.1089/ vbz.2010.0180

43. Zając V, Wójcik-Fatla A, Sawczyn A, Cisak E, Sroka J, Kloc A, et al. Prevalence of infections and co-infections with 6 pathogens in Dermacentor reticulatus ticks collected in eastern Poland. Annals of Agricultural and Environmental Medicine. 2017; 24(1): 26-32. https://doi.org/10.5604/12321966.1233893

44. Tomanović S, Chochlakis D, Radulović Ž, Milutinović M, Ćakić S, Mihaljica D, et al. Analysis of pathogen cooccurrence in host-seeking adult hard ticks from Serbia. Experimental and Applied Acarology. 2013; 59(3): 367-376. https://doi.org/10.1007/s10493-012-9597-y 